\title{
Nilai-Nilai Budaya Sekolah: Studi Kasus Penerapan dan Pengembangan Budaya di SMA Negeri 3 Bantul
}

Fasilatun Khumayroh

Program Studi Pendidikan Agama Islam, Universitas Ahmad Dahlan, Indonesia

\begin{tabular}{|c|c|}
\hline Article Info & ABSTRACT \\
\hline Article history: & This study was conducted to determine the cultural values applied to a \\
\hline Received 2020-02-12 & $\begin{array}{l}\text { particular school in SMA Negeri } 3 \text { Bantul, Yogyakarta. By involving } \\
\text { educators and learners, this study was conducted with descriptive approach to }\end{array}$ \\
\hline Accepted 2020-03-10 & the observation of the school environment, observe, and also interview. From \\
\hline & develop according to the collective agreement as a hallmark of the school and \\
\hline Keywords: & $\begin{array}{l}\text { implemented in daily activities at school by all parties, both educators, } \\
\text { students, and educators. }\end{array}$ \\
\hline
\end{tabular}

Cultura

Educational

Characteristic

\section{Corresponding Author:}

Fasilatun Khumayroh,

Program Studi Pendidikan Agama Islam,

Universitas Ahmad Dahlan,

Email: fasilatun1700031114@webmail.uad.ac.id

\section{PENDAHULUAN}

Undang-Undang no 20 tahun 2003 pasal 1 ayat 2 menyebutkan bahwa "Pendidikan nasional adalah pendidikan yang berdasarkan Pancasila dan Undang-Undang Dasar Negara Republik Indonesia Tahun 1945 yang berakar pada nilai-nilai agama, kebudayaan nasional Indonesia dan tanggap terhadap tuntutan perubahan zaman." Berdasarkan undang-undang tersebut, pendidikan di Indonesia adalah pendidikan yang berakar pada kebudayaan nasional Indonesia. Sekolah sebagai lembaga tempat terselenggaranya kegiatan pendidikan merupakan wadah dalam pembinaan aktivitas keagamaan siswa yang harus mempunyai visi dan misi dalam menciptakan budaya sekolah yang menantang dan menyenangkan, adil, kreatif, inovatif, terintergrasi, dan menghasilkan lulusan yang berkualitas tinggi dalam perkembangan intelektualnya, serta mempunyai karakter takwa, jujur, kreatif, mampu menjadi teladan, bekerjakeras, toleran dan cakap dalam memimpin serta menjawab tantangan akan kebutuhan pengembangan sumberdaya manusia yang dapat berperan dalam perkembangan ilmu pengetahuan dan teknologi dengan tetap berlandaskan pada iman dan taqwa.

Budaya sekolah adalah suatu hal yang menjadi kebiasaan yang dilakukan oleh seluruh personel sekolah dalam setiap aktivitas pendidikan yang terjadi di sekolah. Budaya sekolah menjadi satu ciri khas yang menjadi tolak ukur penilaian masyarakat luar terhadap sekolah tersebut. Itulah kenapa budaya sekolah perlu dipelihara, dijaga, dan dikembangkan sesuai keadaan dan kedudukan dalam bangsa dan negara serta sebagai umat beragama yang mengimplementasikan ajaran agamanya. Budaya sekolah disamping menjadi penilaian terhadap karakter dan akhlak peserta didik juga menjadi bagian dari semangat, motivasi, dan kebanggaan untuk peserta didik maupun pendidik dan tenaga kependidikan yang ada pada satuan pendidikan tersebut.

Budaya sekolah yang kondusif akan mampu mencipatakan suasana pembelajaran yang nyaman, efektif, dan efisien. Disamping itu juga mampu membentuk karakter peserta didik sebagaimana mestinya dan 
menumbuhkan jiwa nasionalisme, semangat kebersamaan dan kesatuan peserta didik.

\section{METODE}

Penelitian ini dilakukan dengan menggunakan jenis penelitian studi kasus untuk mengetahui bagaimana penerapan dan pengembangan budaya di SMA N 3 Bantul. Subjek penelitiannya adalah para pendidik, peserta didik, dan tenaga kependidikan. Dengan menggunakan pendekatan deskriptif, penelitian ini berusaha mengumpulkan informasi melalui wawancara dan observasi lingkungan sekolah.

\section{HASIL DAN PEMBAHASAN}

\subsection{Budaya Sekolah}

Dalam Kamus Besar Bahasa Indonesia, budaya diartikan sebagai: pikiran, adat istiadat, sesuatu yang sudah berkembang, sesuatu yang menjadi kebiasaan yang sukar diubah (Daryanto \& Mohammad Farid, 2013: 215). Kebudayaan sendiri adalah hasil kegiatan dan penciptaan batin (akal budi) manusia, seperti kepercayaan, kesenian dan adat istiadat. Ahli sosiologi mengartikan kebudayaan dengan keseluruhan kecakapan (adat, akhlak, kesenian, ilmu dan lain-lain).

Vijay Sathe berpendapat, "Culture is the set of important assumption (opten unstated) that members of a community share in common (Budaya adalah seperangkat asumsi penting yang dimiliki bersama anggota masyarakat. Hofstede mengartikan budaya sebagai nilai-nilai (values) dan kepercayaan (beliefs) yang memberikan orangorang suatu cara pandang terprogram (programmed way of seeing) (Khaerul Umam. 2012: 90-91).

Budaya merupakan suatu pola asumsi dasar hidup yang diyakini bersama, yang diciptakan, diketemukan, atau dikembangkan oleh sekelompok masyarakat dan dapat digunakan untuk mengatasi persoalan hidup mereka, oleh karenanya diajarkan dan diturunkan dari generasi ke generasi berikutnya, sebagai pegangan perilaku, berpikir, dan rasa kebersamaan diantara mereka.

Menurut Elashmawi dan Harris mengatakan bahwa berbagai bangsa di dunia ini mempunyai budaya yang berbeda satu sama lain. Keanekaragaman tersebut akan berimbas pada perbedaan perilaku, sikap dan juga produk tindakannya. Misalnya saja, budaya organisasi sekolah SMK yang kemudian bisa menghasilkan produk otomotif, berbeda dengan produk dari anak-anak madrasah yang dibesarkan dengan budaya akademik yang berbeda dengan SMK (Momon Sudarma, 2013: 113).

Dari beberapa definisi budaya yang telah dikemukakan dapat diambil pemahaman bahwa budaya adalah seperangkat asumsi, nilai-nilai dan norma yang dikembangkan dalam organisasi yang dijadikan pedoman tingkah laku bagi anggota-anggotanya.

Definisi sekolah, kata "sekolah" berasal dari istilah Yunani "schola" yang artinya waktu luangnya untuk berdiskusi guna menambah ilmu dan mencerdaskan akal. Sekolah merupakan salah satu institusi/lembaga pendidikan formal yang secara khusus didirikan untuk memberikan pelayanan dan menyelenggarakan proses sosialisasi atau pendidikan dalam rangka menyiapkan manusia menjadi individu, warga masyarakat, negara dan dunia di masa depan.

Sekolah sebagai lembaga pendidikan sosial, bisa disebut juga sebagai satu organisasi karena terikat kepada tata aturan formal, berprogram dan bertarget jelas serta memiliki struktur kepemimpinan dalam penyelenggaraan yang resmi. Pada akhirnya fungsi sekolah terikat kepada sasaran yang sasaran yang dibutuhkan oleh masyarakat itu sendiri. Di sekolah diajarkan tentang nilai-nilai dan norma-norma di masyarakat lebih luas. Sekolah berfungsi dalam mengembangkan kecerdasan otak, memberikan pengetahuan, pembentukan spesialisasi, efisiensi pendidikan dan pembelajaran, tempat sosialisasi, tempat tranmisi kultural, dan sebagai kontrol sosial pendidikan (Kompri, 2015: 80-87).

Dalam suatu organisasi (termasuk lembaga pendidikan), budaya diartikan sebagai berikut : Pertama, tindakan yaitu keyakinan dan tujuan yang dianut bersama yang dimiliki oleh anggota organisasi yang potensial membentuk perilaku mereka dan bertahan lama meskipun sudah terjadi pergantian anggota. Dalam lembaga pendidikan misalnya, budaya ini berupa saling menyapa, saling menghargai, toleransi dan lain sebagainya. Kedua, norma perilaku yaitu cara yang sudah lazim digunakan dalam sebuah organisasi yang bertahan lama karena semua anggotanya mewariskan perilaku tersebut kepada anggota baru.

Stolp dan Smith mengemukakan bahwa budaya sekolah sebagai : "school culture can be defined as the historically transmited pattern of meaning that include the norms, values, beliefs, ceremonies, ritual, traditions and myths understood, maybe in varying degress, by members of school community. This system of meaning often shapes what people thinks and how they act". (Ahmad Susanto, 2016: 192). Jadi menurut Stolp dan Smith budaya sekolah diartikan sebagai sejarah tentang pola penyampaian sebuah arti yang termasuk di dalamnya adalah norma, nilai, kepercayaan, upacara ritual, tradisi, dan mitos, mungkin itu yang membedakan tingakatan dari anggota dalam komunikasi sekolah. Sistem ini yang sering membentuk apa yang orang pikirkan dan bagaimana mereka bertindak. 
Menurut Terrence Deal dan Kent Peterson bahwa budaya sekolah berkenaan dengan nilai kebersamaan (shared values), ritual dan sinbol-simbol. Mereka menyatakan bahwa inti permasalahan sekolah bukan pada masalah teknis tetapi pada masalah sosial. Budaya melayani pelanggan yang menekankan pada kualitas pelayanan sehingga dapat mengubah sikap dan perilaku pekerja terhadap pelanggan dan menyebabkan meningkatnya kepuasaan pelanggan dan penjualan. Apabila pekerja merasa sesuai dengan budaya organisasi sekolah maka mereka akan cenderung mengembangkan kedekatan emosional terhadap organisasi (Wesly Hutabarat, 2015: 19).

Dengan demikian dapat dikemukakan bahwa budaya sekolah merupakan suatu sistem nilai-nilai, norma, dan interaksi-interaksi yang diperkenalkan dan diajarkan serta diterapkan di sekolah untuk mempengaruhi pola pikir, sikap dan perilaku seluruh pendidik, peserta didik, dan tenaga kependidikan dalam suatu satuan pendidikan.

Budaya sekolah sebenarnya dapat dikembangkan terus-menerus kearah yang lebih positif. aspek-aspek mengenai budaya utama yang direkomendasikan untuk dikembangkan sekolah yaitu sebagai berikut: 1). Budaya jujur adalah budaya yang menekankan pada aspek-aspek kejujuran pada masyarakat dan temanteman. 2). Budaya saling percaya adalah budaya yang mengkondisikan para siswa dan warga sekolah untuk saling mempercayai orang lain. 3). Budaya kerja sama adalah budaya yang membuat orang-orang saling membantu dalam berbagai hal untuk mencapai tujuan. 4). Budaya membaca adalah budaya yang membuat seseorang menjadi gemar membaca. 5). Budaya disiplin dan efisien adalah budaya taat dan patuh terhadap nilai-nilai yang dipercayai termasuk melakukan pekerjaan tertentu yang menjad tanggung jawabnya. 6). Budaya bersih adalah budaya yang mengajarkan tentang bagaimana menjaga kebersihan baik badan maupun lingkungan. 7). Budaya berprestasi adalah budaya yang menciptakan kondisi yang kompetitif untuk memacu prestasi siswa. 8). Budaya memberi penghargaan dan menegur adalah budaya yang memberikan respon dengan menyapa pada setiap orang yang ditemui (Direktorat Pendidikan Menengah Umum Depdiknas, 2003)

\subsection{Asal Mula Budaya}

Kebiasaan, tradisi, dan cara umum dalam melakukan segala sesuatu yang ada di sebuah organisasi atau sekolah, saat ini merupakan hasil atau akibat dari yang telah dilakukan sebelumnya dan seberapa besar kesuksesan yang telah diraihnya pada masa lalu. Hal ini mengarah pada sumber tertinggi sebuah budaya antara lain para pendirinya. Secara tradisional, pendiri organisasi memiliki pengaruh besar terhadap budaya awal organisasi tersebut. Pendiri organisasi atau sekolah tidak memiliki kendala karena kebiasaan atau ideology sebelumnya (Robbins Stephen P, Judge Timothy A, 2008: 256-266).

Proses menciptakan budaya terjadi dalam tiga cara antara lain : Pertama, pendiri hanya merekrut dan mempertahankan anggota atau karyawan yang memiliki pikiran dan perasaan yang sama dengan mereka. Kedua, pendiri melakukan indoktrinasi dan menyosialisasikan cara pikir dan berperilakunya kepada karyawan atau anggota. Ketiga, perilaku pendiri sendiri bertindak sebagai model yang berperan mendorong karyawan untuk mengidentifikasi diri dengan demikian, karyawan dapat menginternalisasi keyakinan, nilai dan asumsi pendiri tersebut (Schein, E.H, 1996: 61-62).

\subsection{Karakteristik Budaya Sekolah}

Setiap sekolah memiliki budaya masing-masing yang menjadi ciri khas yang mencerminkan sekolah tersebut dan membedakan dari sekolah-sekolah lainnya. Hal ini yang menjadi salah satu unsur penilaian masyarakat luar terhadap suatu sekolah.

Setiap budaya sekolah memiliki karakteristik yang berbeda-beda pula. Untuk mengetahui perbedaanperbedaan tersebut, dapat dilihat dari beberapa hal menurut Saphier dan King sebagai berikut: Kolegalitas. Merupakan iklim kesejawatan yang menimbulkan rasa saling menghormati dan menghargai sesama profesi kependidikan. Eksperimen. Sekolah merupakan tempat yang cocok untuk melakukan percobaan-percobaan ke arah menemukan pola kerja (seperti model pembelajaran) yang lebih baik dan diharapkan menjadi milik sekolah. High expectation. Keleluasaan budaya sekolah yang memberi harapan kepada setiap orang untuk memperoleh prestasi tertinggi yang pernah dicapai. Trust and confidence. Kepercayaan dan keyakinan yang kuat merupakan bagian terpenting dalam kehidupan suatu profesi. Budaya sekolah yang kondusif akan memberikan peluang bagi setiap orang supaya percaya diri dan memiliki keyakinan terhadap insentif yang akan diterima atas dasar gagasan baru yang diberikannya untuk organisasi. Tangible and support. Budaya sekolah mendukung lahirnya perbaikan pembelajaran serta mendorong terciptanya pengembangan profesi dan keahlian. Reaching out to the knowledge base. Sekolah merupakan tempat pengembangan ilmu secara luas, objektif dan proporsional, pengkajian, pengembangan gagasan baru, penelitian, pengembangan konsep baru semuanya memerlukan pemahaman landasan keilmuannya terlebih dahulu. Appreciation and recognation. Budaya sekolah memelihara penghargaan dan pengakuan atas prestasi guru sehingga menjunjung tinggi harga diri guru. 
Caring, celebration, and humor. Memberi perhatian, saling menghormati, memuji, dan memberi penghargaan atas kebaikan seorang guru di sekolah adalah perbuatan yang terpuji. Humor dan saling menggembirakan adalah budaya pergaulan yang sehat. Involvement in decision making. Budaya sekolah yang melibatkan staf turut serta dalam pembuatan keputusan menjadikan masalah menjadi transparan dan semua staf sekolah dapat mengetahui masalah yang dihadapi dan bersama-sama memecahkannya. Protection of what's important. Memelihara dan menjaga kerahasian pekerjaan merupakan budaya di sekolah. Budaya sekolah yang baik akan mengetahui mana yang harus dibicarakan dan apa yang harus dirahasiakan. Tradition. Memelihara tradisi yang sudah berjalan lama dan di anggap baik adalah budaya dalam lingkungan sekolah dan biasanya sukar untuk ditiadakan, seperti tradisi wisuda, upacara bendera, penghargaan atas jasa atau prestasi dan sebagainya. Honest, open communication. Kejujuran dan keterbukaan di lingkungan sekolah dan seharusnya terpelihara, karena sekolah merupakan lembaga pendidikan yang membentuk manusia yang jujur, cerdas, dan terbuka baik oleh pemikiran baru ataupun oleh perbedaan pendapat (Ahmad Susanto, 2016: 193-194).

\subsection{Fungsi Budaya Sekolah}

Budaya sekolah berfungsi sebagai tolak ukur penilaian masyarakat luar terhadap sekolah tersebut karena budaya sekolah adalah cerminan dari pembentukan karakter yang coba dibangun dan diusahakan oleh sekolah tersebut. Budaya sekolah menjadi identitas yang membedakan satu sekolah dengan yang lainnya karena ciri khas yang ada dalam budaya tersebut. Disamping itu budaya sekolah juga berfungsi sebagai penambah semangat, motivasi, dan rasa bangga seluruh personel sekolah, baik itu pendidik, peserta didik, maupun tenaga kependidikan lainnya.

Menurut Peterson, kenapa budaya sekolah penting dipelihara adalah karena beberapa alasan sebagai berikut : Budaya sekolah mempengaruhi prestasi dan perilaku sekolah. artinya bahwa budaya menjadi dasar bagi siswa dapat meraih prestasi melalui ketenangan yang diciptakan iklim dan peluang-peluang kompetetitif yang diciptakan program sekolah. Budaya sekolah tidak tercipta dengan sendirinya, tetapi memerlukan tangantangan kreatif, inovatif, dan visioner untuk menciptakan dan menggerakkannya. Budaya sekolah adalah unik walaupun mereka menggunakan komponen yang sama tetapi tidak ada dua sekolah yang persis sama. Budaya sekolah memberikan kepada semua level manajemen untuk fokus pada tujuan sekolah dan budaya menjadi kohesi yang mengikat bersama dalam melaksanakan misi sekolah. Meskipun demikian, budaya dapat menjadi counter productive dan menjadi suatu rintangan suksesnya bidang pendidikan dan budaya dapat bersifat membedakan dan menekankan kelompok-kelompok tertentu di dalam sekolah. Perubahan budaya merupakan suatu proses yang lambat, seperti perubahan cara mengajar dan struktur pengambilan keputusan (Ahmad Susanto, 2016: 195).

Robbins menjelaskan, ada lima fungsi budaya dalam organisasi (Robbins, Stephen P, 2006: 283), yaitu: Budaya berperan sebagai batas-batas penentu. Budaya menciptakan perbedaan antara satu organisasi dengan organisasi yang lain. Mengantarkan suatu perasaan identitas bagi anggota organisasi. Mempermudah timbulnya komitmen yang lebih luas dari pada kepentingan individual seseorang. Meningkatkan stabilitas sistem sosial karena merupakan perekat sosial yang membantu mempersatukan organisasi. Sebagai mekanisme control dan rasional yang memandu dan membentuk sikap serta perilaku karyawan.

Menurut Schein "budaya sebagai landasan dasar anggapan dan kepercayaan bersama seluruh anggota organisasi. Jika budaya organisasi merupakan aspek penting dalam meningkatkan kinerja maka budaya organisasi harus dikelola dengan baik. Untuk dapat mengelola dengan baik diperlukan pengertian yang jelas dan perhatian terhadap budaya organisasi. Budaya itu mewakili persepsi bersama yang dianut oleh para organisasi untuk menentukan perilaku anggota organisasi”. Pendidikan juga merupakan suatu organisasi, seperti yang sudah dijelaskan pada awal pembahasan (Yulk,Gary, 1994: 332).

\subsection{Penerapan dan Pengembangan Budaya SMA Negeri 3 Bantul, Yogyakarta}

Berdasarkan data dari beberapa sumber di lapangan yang dapat penulis kemukakan secara umum, penerapan dan pengembangan budaya di SMA Negeri 3 Bantul Yogyakarta berjalan dengan baik. Sekolah ini sudah terakreditasi A dan beralamatkan di Jalan Pramuka, Gaten, Trirenggo, Bantul, Trirenggo, Kec. Bantul, Kab. Bantul Prov. D.I. Yogyakarta.

Sekolah ini menerapkan budaya 3S yaitu Senyum, Sapa, dan Salam pada seluruh warga sekolah SMA Negeri 3 Bantul. Seperti contoh pada pagi hari, beberapa pendidik menyambut peserta didik yang mulai berdatangan di gerbang sekolah. Pun ketika berpapasan saat istirahat atau kapanpun itu ketika masih di sekolah, seluruh warga sekolah berusaha menerapkan 3S. Budaya ini 3S ini begitu sederhana namun memiliki impact atau dampak yang cukup mengesankan bagi seluruh warga sekolah. Dengan budaya $3 \mathrm{~S}$ ini maka timbullah rasa kekeluargaan, kebersamaan, rasa saling toleransi, menghargai satu sama lain dan menghormati kepada yang lebih tua. 
Sebagian besar peserta didik membawa sepeda motor untuk berangkat dan pulang dari sekolah. Setiap paginya, sudah ada beberapa pendidik yang akan menyambut kedatangan peserta didik didepan pintu gerbang sekolah. Peserta didik yang membawa sepeda motor diharuskan untuk mematikan mesin nya ketika sudah sampai didepan gerbang sekolah dan mendorongnya untuk sampai kepada tempat parkir motor yang sudah disediakan oleh pihak SMA Negeri 3 Bantul. Sembari mendorong sepeda motornya, mereka melakukan atau menerapkan budaya $3 \mathrm{~S}$ seperti yang sudah disebutkan pada pembahasan sebelumnya.

Budaya 3S juga diterapkan ketika peserta didik berpapasan dengan peserta didik yang lainnya, baik mereka pada kelas yang sama atau tidak. Sesampainya mereka di ruang kelas, beberapa peserta didik yang memang sudah dijadwalkan untuk piket di hari itu akan bergegas untuk mengambil alat kebersihan dan membersihkan ruangan kelas. Disamping itu mereka juga bertugas untuk memastikan ketersediaan sumber belajar yang akan digunakan untuk pembelajaran pada hari itu. Baik itu spidol, buku paket Dan lain sebagainya. Jadwal piket kelas memang sudah ditentukan dari setiap masing-masing kelas sesuai dengan kesepakatan bersama. Piket membersihkan kelas dilakukan pada pagi hari sebelum pembelajaran dimulai dan pada siang hari setelah pembelajaran selesai.

Setiap paginya, sebelum pembelajaran dimulai biasa dilaksanakan kegiatan tadarus Al-Qur'an. Harapannya adalah bahwa setiap apa yang dilakukan dimulai dengan mengingat-Nya sehingga mendapatkan ridho dan keberkahan dari-Nya. Bagi peserta didik yang non-muslim, mereka juga ada waktu untuk berdoa sesuai dengan keyakinannya. Kegiatan tadarus Al-Qur'an juga dilakukan pada jam pelajaran Pendidikan Agama Islam, tadarus dengan membaca Al-Qur'an bersama-sama dan dipimpin langsung oleh guru pengampu mata pelajaran tersebut. Kegiatan tadarus ini merupakan suatu budaya yang baik untuk dikembangkan. Dengan kegiatan ini memungkinkan peserta didik untuk meningkatkan keimanannya dan kecintaannya terhadap agama yang dianutnya. Sehingga untuk kedepannya mampu mengimplementasikan ajaran agama sesuai dengan Al-Qur'an dan Sunnah bagi mereka yang beragama islam, serta sesuai kitabnya bagi mereka yang beragama non islam. Dengan begitu, lambat laun akan membentuk karakter peserta didik yang insyaaAllah berakhlakul karimah dan menjadi seseorang yang bermanfaat bagi dirinya sendiri, orang lain, negara, bangsa, dan agamanya.

Kegiatan pembelajaran berlangsung mulai pukul 07.00-14.00 WIB dan dilanjut dengan kegiatan ekstrakurikuler sampai maksimal pukul 17.00 WIB. Setiap memasuki waktu sholat fardhu, yaitu dzuhur dan asar semua kegiatan yang sedang berlangsung diberhentikan dan seluruh warga sekolah dihimbau untuk bersama-sama sholat berjamaah di masjid SMA Negeri 3 Bantul. Kecuali bagi mereka yang non muslim.

SMA Negeri 3 Bantul adalah sekolah yang menerapkan budaya bersih, terbukti bahwa setiap sekali dalam satu bulan SMA Negeri 3 Bantul mengadakan Hari Cinta Lingkungan. Hari tersebut adalah hari dimana seluruh warga sekolah bekerja sama bahu membahu Dan bergotong royong untuk membersihkan seluruh area sekolah, baik yang didalam ruangan kelas, maupun di luar ruangan kelas, bahkan di lingkungan sekitar sekolah. Pada hari tersebut, seluruh warga sekolah mengenakan seragam olahraga atau pakaian training dan semacamnya. Dengan Hari Cinta Lingkungan ini, peserta didik diajarkan untuk mencintai, menjaga, dan mensyukuri alam sekitarnya sebagai nikmat yang diberikan Tuhan kepada hamba-Nya. Disamping itu, peserta didik juga belajar arti kebersamaan, saling bekerja sama, toleran, dan saling menghargai satu dengan yang lainnya.

\section{KESIMPULAN}

Budaya sekolah merupakan suatu sistem nilai-nilai, norma, dan interaksi-interaksi yang diperkenalkan dan diajarkan serta diterapkan di sekolah untuk mempengaruhi pola pikir, sikap dan perilaku seluruh pendidik, peserta didik, dan tenaga kependidikan dalam suatu satuan pendidikan. Secara tradisional, pendiri organisasi memiliki pengaruh besar terhadap budaya awal organisasi tersebut. Setiap sekolah memiliki budaya masing-masing yang menjadi ciri khas yang mencerminkan sekolah tersebut dan membedakan dari sekolah-sekolah lainnya. Budaya sekolah sebagai identitas suatu sekolah berfungsi sebagai tolak ukur penilaian masyarakat luar terhadap sekolah tersebut karena budaya sekolah adalah cerminan dari pembentukan karakter yang coba dibangun dan diusahakan oleh sekolah tersebut. Penerapan dan pengembangan budaya di SMA Negeri 3 Bantul sudah cukup baik. Sekolah ini menerapkan 3S, budaya rapi dan bersih dengan adanya jadwal piket Dan hari cinta ligkungan, serta tadarus di pagi hari dan sholat fardhu dengan berjamaah sebagai sarana untuk pembentukan karaktr peserta didik dan meningkatkan keimanannya untuk kemudian mampu mengimplementasikan pada kehidupan sehari-harinya dengan akhlakul karimah. 


\section{REFERENSI}

Ahmad Susanto. Manajemen Peningkatan Kinerja Guru : Konsep, Strategi, dan Implementasinya, Jakarta : Kencana, 2016.

Daryanto \& Mohammad Farid. Konsep Dasar Manajemen Pendidikan di Sekolah, Yogyakarta : Gava Media, 2013.

Direktorat Pendidikan Menengah Umum Depdiknas, Pedoman Pengembangan Kultur Sekolah, Jakarta: Depdiknas, 2003.

Khaerul Umam. Manajemen Organisasi, Bandung : Pustaka Setia, 2012.

Kompri. Manajemen Pendidikan : Komponen-Komponen Elementer Kemajuan Sekolah, Yogyakarta : ArRuzz Medan, 2015

Momon Sudarma. Profesi Guru : Dipuji, Dikritisi, dan Dicaci, Jakarta : PT Raja Grafindo Persada, 2013.

Robbins Stephen P, Judge Timothy A, Perilaku Organisasi, Jakarta: Cetakan ke 2 Salemba Empat, 2008.

Schein, E.H."Leadership and Organizational Culture," The Leader of the Future, Jossey Bass, San Fransisco: 1996.

Wesly Hutabarat. Mengukur Kimerja Guru Profesional, Jakarta : Halaman Moeka Publishing, 2015.

Yulk, Gary. Leadership In Organizations.Prentice Hal lInternational, America: 1994. 